\title{
Large coronary artery fistula and patent ductus arteriosus: transcatheter closure with three PDA nitinol wire mesh occluders
}

Duża przetoka wieńcowa i drożny przewód tętniczy - przezcewnikowe zamknięcie trzema nitinolowymi korkami przeznaczonymi do zamykania drożnego przewodu tętniczego

\author{
Jacek Bialkowski', Malgorzata Szkutnik', Gejung Zhang², Shilinag Jiang ${ }^{2}$ \\ ${ }^{1}$ Congenital Heart Diseases and Pediatric Cardiology Department, Medical University of Silesia, Silesian Center for Heart Diseases, Zabrze, \\ Poland \\ 2National Center for Cardiovascular Diseases, Chinese Academy of Medical Science, Peking Union Medical College, Fuwai Hospital, Beijing, \\ China
}

Postep Kardiol Inter 2013; 9, 1 (31): 89-92

DOI: $10.5114 /$ pwki.2013.34032

\begin{abstract}
Coronary artery fistulas (CAF) are the most common congenital anomaly of this vessel. We present the case of a 26 -year-old man with two coexisting congenital cardiac defects: patent ductus arteriosus (PDA) and CAF. The patient 3 months earlier had the transcatheter PDA closed (type A, diameter $4 \mathrm{~mm}$ ) with a 10/8 mm PDA nitinol wire mesh occluder. After the procedure he continued to have symptoms of fatigue and continuous murmur in the precordial region persisted. In angio-CT a large coronary fistula from the circumflex coronary artery with suspicion of multiple orifices to the right atrium was found. An arteriovenous wire loop was created (guidewire introduced from the aorta through the CAF was snared using a lasso catheter in the superior vena cava and exteriorized through the right femoral vein). Retrogradely an $8 \mathrm{~F}$ long sheath and delivery system was introduced to the end of the fistula and a 12/10 mm Cardio-O-Fix PDA occluder (Starway Comp, China, Beijing) was implanted, closing one orifice of the CAF. Another leak (orifice of CAF - $3.5 \mathrm{~mm}$ diameter) was closed using a similar technique with a 10/8 mm PDA Cardio-O-Fix device. Complete closure of the coronary artery fistula and disappearance of the heart murmur were observed after the procedure. The patient was discharged home 4 days later on acetylsalicylic acid $150 \mathrm{mg} /$ day. During 6 months of follow-up he was doing well without any complaints or pathological symptoms. In control angio-CT performed 3 months after the procedure complete closure of the CAF was confirmed.
\end{abstract}

Key words: coronary artery fistula, patent ductus arteriosus, transcatheter closure.

\section{Streszczenie}

Przetoki tętnic wieńcowych (coronary artery fistulas - CAF) są najczęstszą wrodzoną anomalią tych naczyń. W pracy przedstawiono przypadek 26-letniego pacjenta z dwiema wspótistniejącymi wadami wrodzonymi: drożnym przewodem tętniczym (patent ductus arteriosus - PDA) i dużą CAF. U pacjenta 3 miesiące wcześniej przezcewnikowo zamknięto PDA (typ A o średnicy 4 mm) za pomocą nitinolowego korka PDA o rozmiarze 10/8 mm. Po zabiegu nadal występowała zwiększona męczliwość oraz stwierdzano ciągły szmer w okolicy przedsercowej. W angio-TC uwidoczniono dużą przetokę wieńcową odchodzącą od tętnicy okalającej z mnogimi ujściami do prawego przedsionka. Za pomocą prowadnika wykonano pętlę tętniczo-żylną (prowadnik wprowadzono od aorty poprzez CAF do żyły głównej górnej, gdzie został uchwycony pętlą i wyprowadzony na zewnątrz przez żyłę udową). Odżylnie do przetoki wieńcowej wprowadzono koszulkę naczyniową 8 F i zestaw wprowadzający z nitinolowym korkiem 12/10 mm PDA Cardio-O-Fix occluder (Starway Medical Comp, China, Beijing). Po odłączeniu implantu zamknięto pierwsze ujście CAF. Kolejne ujście CAF (o średnicy 3,5 mm) zamknięto za pomocą tej samej techniki, stosując 10/8 mm PDA Cardio-O-Fix occluder. Uzyskano całkowite zamknięcie przetoki oraz ustąpienie szmeru nad sercem. Pacjenta wypisano do domu po 4-dniowym pobycie w szpitalu z zaleceniem stosowania 150 mg kwasu acetylosalicylowego przez 6 miesięcy. Podczas 6-miesięcznej obserwacji mężczyzna pozostaje w dobrym stanie, nie stwierdza się objawów choroby. W kontrolnym angio-CT wykonanym 3 miesiące po zabiegu potwierdzono całkowite zamknięcie CAF.

Słowa kluczowe: przetoka wieńcowa, drożny przewód tętniczy, przezcewnikowe zamknięcie. 


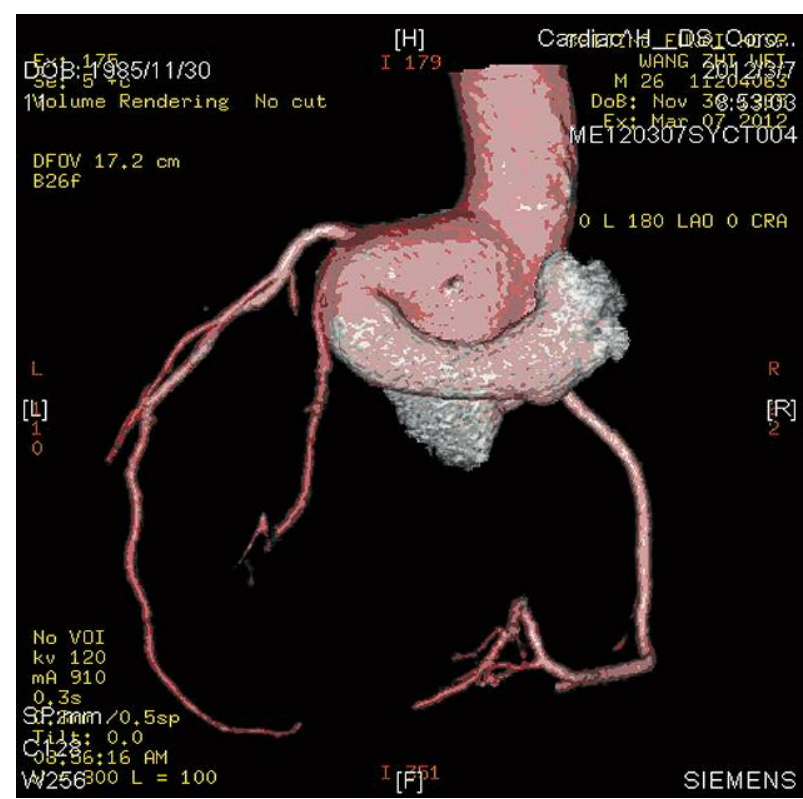

Fig. 1. Computed tomography. Huge left circumflex artery to right atrium fistula (posterior view)

Ryc. 1. Tomografia komputerowa. Wielka przetoka wieńcowa z tętnicy okalającej do prawego przedsionka (widok od tyłu)

\section{Introduction}

Coronary artery fistulas (CAF) are the most common anomalies of the coronary artery. Origin of the fistula from the left coronary is more common than the right (75\% vs. $25 \%$ ) and entry sites were in the right heart in 92\% (pulmonary artery $33 \%$, ventricle $32 \%$, atrium $24 \%$ ). Most often the entry point was a single orifice and rarely multiple. Coronary fistulas are thought to have a congenital origin and enlarge gradually throughout life [1]. The American College

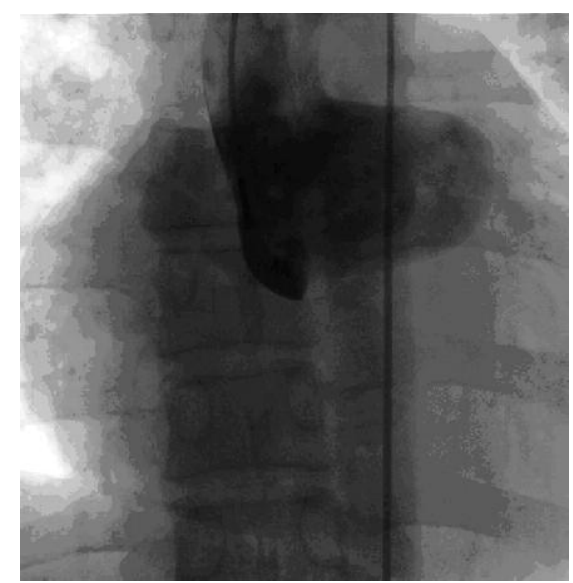

Fig. 2. The same image as in Figure 1 in aortography (PA view)

Ryc. 2. Ten sam obraz co na ryc. 1. w aortografii (projekcja PA) of Cardiology/American Heart Association 2008 guidelines for the management of adults with congenital heart diseases recommended the closure of all large coronary artery fistulas, regardless of symptomatology, using transcatheter or surgical techniques [2].

\section{Aim}

We would like to present the case of two special peculiarities: presence of patent ductus arteriosus coinciding with multiple orifices of the coronary artery fistula to the right atrium. All undesirable circulatory connections were closed during interventional catheterizations.

\section{Case report}

A 26-year-old man (68 kg body weight) was admitted with symptoms of fatigue, with continuous murmur at the left sternal border. Three months previously he was diagnosed with patent ductus arteriosus (PDA), which was closed percutaneously. The mean diameter of PDA was $4 \mathrm{~mm}$, pulmonary artery pressure 21/7/12 $\mathrm{mm} \mathrm{Hg}$ and aortic 100/60/70 mm Hg, Qp/Qs ratio - 3.0. Patent ductus arteriosus was type $A$ (according to Kirchenco classification and it was closed uneventfully with a PDA $10 / 8 \mathrm{~mm}$ device (Lifetech Comp, Shenzen, China). After the procedure continuous murmur persisted. Electrocardiography was normal and in thoracic X-ray slight enlargement of the right atrium and augmented pulmonary flow in both lungs were observed. Based on the detailed transthoracic echocardiogram the presence of coronary artery fistula to the right atrium was suspected. In angio-CT left circumflex artery with possible multiple orifices to the right atrium was confirmed (Figure 1). The patient was referred for diagnostic and possible therapeutic catheterization. Written consent was obtained from the patient to perform that procedure.

Vascular access was obtained through the right femoral artery (sheath $6 \mathrm{~F}$ ) and right femoral vein (sheath $8 \mathrm{~F}$ ).

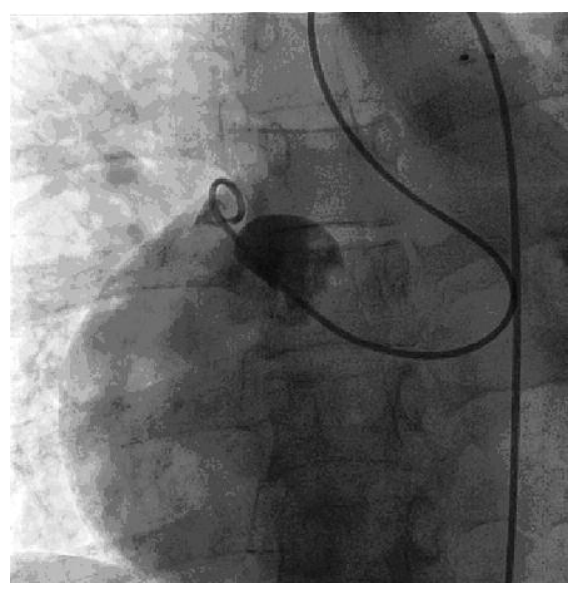

Fig. 3. Crossing the fistula to right atrium with Pigtail catheter

Ryc. 3. Przejście przez przetokę do prawego przedsionka cewnikiem Pigtail 


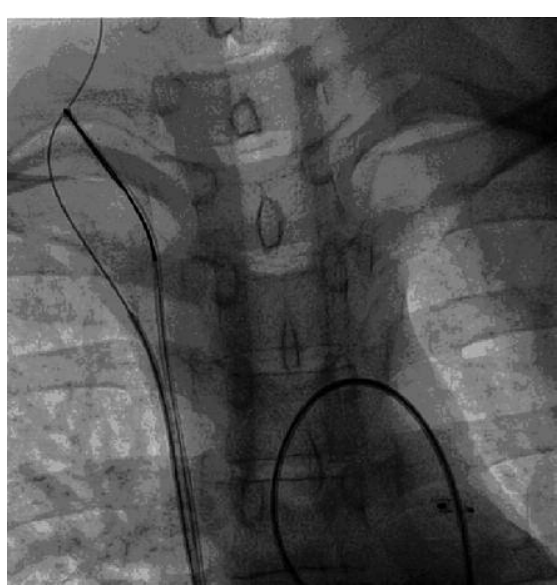

Fig. 4. Arteriovenous loop creation

Ryc. 4. Utworzenie pętli tętniczo-żylnej

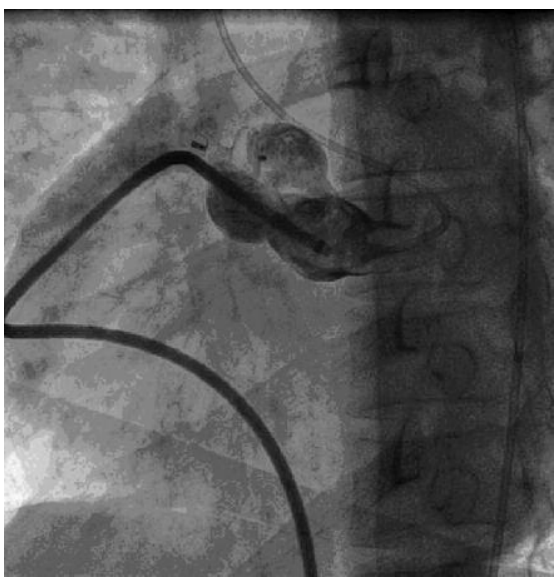

Fig. 6. Delivery sheath crossing another orifice of the fistula. First PDA occluder already detached in the position

Ryc. 6. Koszulka wprowadzająca umieszczona przez drugie ujście przetoki. Pierwszy implant już odłązony, w stabilnej pozycji

Heparin and antibiotic were administered. Aortography confirmed the presence of a huge CAF to the right atrium (Figure 2). A $6 \mathrm{~F}$ pigtail catheter with the aid of a Terumo hydrophilic guide wire $0.35 \mathrm{~cm} \times 260 \mathrm{~cm}$ was inserted into the dilated circumflex artery and later to the right atrium through the $6 \mathrm{~mm}$ orifice (Figure 3). The wire was snared using a lasso catheter in the superior vena cava (Figure 4) and exteriorized in the right femoral vein for the creation of an arteriovenous wire loop. With the $8 \mathrm{~F}$ delivery system the 12/10 Cardio-O-Fix (COF) PDA occluder (Starway Comp, China, Beijing) was opened (Figure 5), closing one orifice of the CAF. Another leak (orifice of CAF - $3.5 \mathrm{~mm}$ diameter) was closed using a similar technique by a 10/8 mm PDA

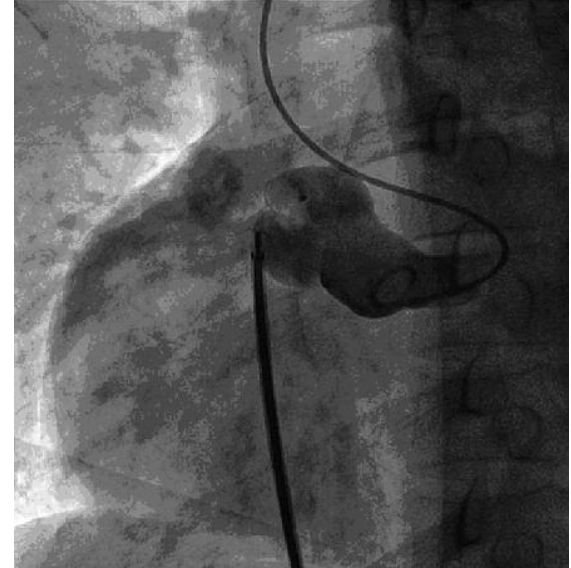

Fig. 5. Closure of the fistula with first $10 / 12 \mathrm{~mm}$ Cardio-O-Fix PDA Occluder. Angiography in fistula lumen shows additional leak to right atrium is present Ryc. 5. Zamknięcie przetoki pierwszym implantem 10/12 mm Cardio-O-Fix. Angiografia ukazuje drugi przeciek do prawego przedsionka

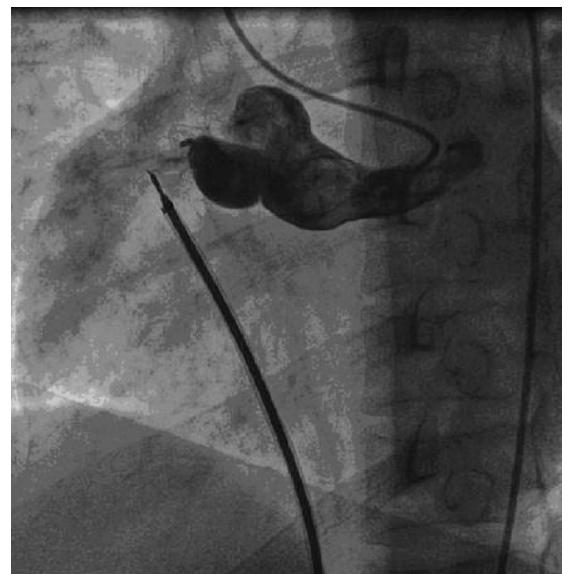

Fig. 7. Deployment of the second 10/8 mm PDA Cardio-O-Fix occluder (device still attached to delivery system)

Ryc. 7. Otwarcie drugiego implantu 10/8 PDA Cardio-O-Fix (zestaw nadal połaczony z zestawem wprowadzającym)

COF device (Figure 6-9). Complete closure of the coronary artery fistula and disappearance of the heart murmur were observed. The patient was discharged home 4 days after the procedure on acetylsalicylic acid $150 \mathrm{mg} /$ day. During 6month follow-up he remained without any complaints or pathological symptoms. In control angio-CT complete closure of the CAF was confirmed.

\section{Discussion}

Coronary artery fistula is an uncommon congenital malformation. Echocardiographic examination in case of CAF does not always show detailed anatomy. In such cases the usefulness of angio-CT has been confirmed in several stud- 


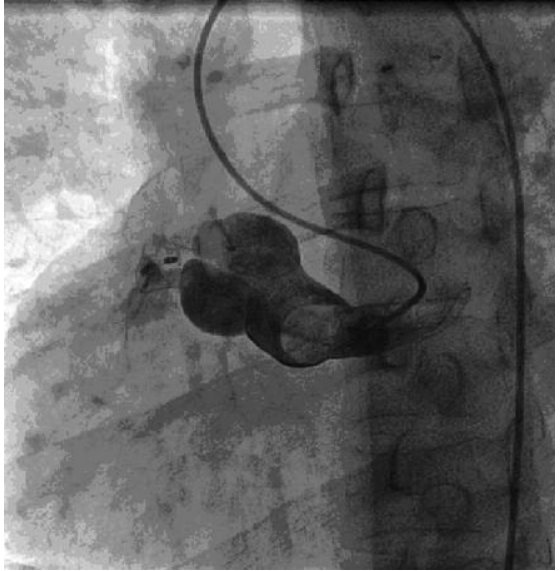

Fig. 8. Angiography in the fistula showing almost complete occlusion

Ryc. 8. Angiografia w przetoce wskazuje na prawie catkowite zamknięcie przecieku

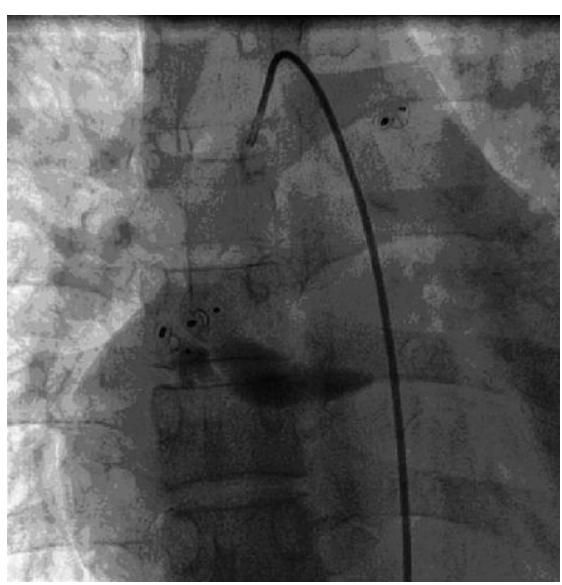

Fig. 9. Final fluoroscopy. Note presence of 2 PDA occluders closing fistula (persistent contrast presence in the lumen of closed fistula), as well as third one closing PDA

Ryc. 9. Końcowa fluoroskopia. Widoczne 2 okludery PDA zamykajace przetokę (utrzymywanie się kontrastu $w$ świetle zamkniętej przetoki) oraz trzeci okluder zamykajacy PDA

ies [3, 4], as well as ours. Coexistence of PDA and coronary artery fistula is very rare and was described previously in one of our patients [5]. Continuous murmur is characteristic for large coronary artery fistula and was present in all previously published patients [4-8]. This murmur is present also in case of PDA, which can cloud the presence of coexisting CAF, as happened in our case. Persistent continuous murmur after successful closure of the PDA was the main reason to find out another cardiac pathology.
All cases published previously [4-8] had only one fistula orifice. In the patient described in this paper, multiple (at least 2) orifices of the coronary artery fistula were present. Our experience shows that precisely chosen devices can effectively close such CAFs. Successful percutaneous closure of large coronary artery fistula has been reported previously mainly using an Amplatzer Duct Occluder (ADO) [4, $5,8]$. This implant has several advantages over other devices used to close CAFs including a high rate of complete occlusion and relatively easy implantation. On the other hand, the experience presented here, as well as by others $[6,7]$, indicates that Chinese devices, very similar to ADO, also fulfill these requirements. The choice of the device and technique for percutaneous closure of coronary artery fistula depends on anatomical characteristics of the fistula. Patent ductus arteriosus nitinol wire occluders are a good option for such purposes.

\section{Conclusions}

Transcatheter closure of large coronary artery fistula with multiple orifices is safe and effective.

\section{Acknowledgments}

The described procedure was performed during the China Interventional Therapeutics Congress on 16 March 2012 in Beijing, China.

\section{References}

1. Keane JF, Fyler DC. Vascular fistule. In: Nadas pediatric cardiology. Keane JF, Lock, JE, Flyler DC (eds). Saunder Elsevier, Philadelphia 2006; 799-804.

2. Warnes CA, Williams RG, Bashore TM. The American College of Cardiology/American Heart Association 2008 guidelines for the management of adults with congenital heart diseases: a report of ACC/AHA task force on practice guidelines (Writing Committee to develop guidelines for the management of adults with congenital heart diseases). J Am Coll Cardiol 2008; 52: e1-e121.

3. Wasniewski M, Angerer D, Ochotny R, et al. The 64-slice computed tomography of a coronary artery fistula communicating with right ventricle. Cardiol J 2008; 15: 384-385.

4. Wisniewska-Szmyt J, Swiatkiewicz I, Chojnicki M, et al. Percutaneous closure of the coronary artery fistula connecting left main coronary artery and the right atrium in a 61 year-old woman. Kardiol Pol 2011; 69: 734-737.

5. Xu L, Xu Z, Jiang S, et al. Transcatheter closure of coronary artery fistula in children. Chin Med J 2010; 123: 822-826.

6. Bialkowski J, Szkutnik M, Fiszer R, et al. Transcatheter occlusion of a large coronary artery fistula using a patent ductus arteriosus occluder. Kardiol Pol 2011; 69: 1318-1319.

7. Zhao G, Jin H, Wu H. Successful closure for a case of congenital coronary artery fistula using a patent ductus arteriosus occluder. Cardiol Young 2011; 21: 97-100.

8. Hakim F, Madani A, Goussouos Y, et al. Thranscatheter closure of large coronary arteriovenous fistula using the new Amplatzer duct occluder. Cathet Cardiovasc Diag 1998; 45: 155-157. 